\title{
骨盤骨折に伴う後部尿道外傷性狭窄の形成術後の妊孕能について
}

$$
\begin{aligned}
& \text { 聖マリアンナ医科大学泌尿器科学教室 (主任: 長田尚夫) } \\
& \text { 岩本 晃明 矢島 通孝 } \text { 山越 昌成 } \\
& \text { 黒子 幸一 }
\end{aligned}
$$

\section{FERTILITY IN PATIENTS AFTER SURGICAL REPAIR OF MEMBRANOUS URETHRAL STRICTURES ASSOCIATED WITH PELVIC FRACTURES}

\author{
Teruaki Iwamoto, Michitaka Yajima, Masanari Yamagoe, Koichi Kuroko, \\ Takeo Inoue and Takao Osada \\ Department of Urology, St. Marianna University School of Medicine \\ (Director: Prof. T. Osada)
}

We evaluated fertility in fourteen patients after surgical repair of membranous urethral strictures associated with pelvic fractures. Eight patients were operated on using Badenoch's method (pull through) and six patients by end-to-end anastomosis of the urethra. All of them have maintained libido and potency after urethroplasty. No ejaculatory disturbance had ever occurred since surgery. Semen analysis was evaluated three months to four years after urethroplasty and serum hormone levels were measured in four patients.

The results were as follows: 1) All except 2 patients had normal semen volume (more than $2 \mathrm{ml}) .2$ ) Nine patients $(64 \%)$ had a sperm density of more than $40 \times 106 / \mathrm{ml}$. Two patients had a sperm density of 20 to $40 \times 10^{6} / \mathrm{ml}$ and three patients less than $20 \times 10^{6} / \mathrm{ml}$. 3) Nine patients $(64 \%)$ had a sperm motility of more than $50 \%$, three $30-50 \%$ and two less than $30 \%$. 4) Seven patients (50\%) had normal semen findings with a sperm density of more than $20 \times 10^{6} / \mathrm{ml}$ and a sperm motility of more than $50 \%$ according to the WHO laboratory manual. 5) Pyospermia (WBC $\geqq 10 / \mathrm{hpf}$ ) was observed in three patients. However, they never had subjective symptoms or objective findings of inflammation. 6) Serum LH, FSH, testosterone and PRL levels were within normal limits. 7) After urethroplasty, two patients married and their wives became pregnant.

In conclusion, these results indicate that surgical repair of membranous urethral strictures associated with pelvic fractures has little effect on fertility.

Key words: membranous urethral stricture, urethroplasty, fertility

\footnotetext{
要旨：骨盤骨折に伴なら後部尿道外傷性狭窄の形成術後の妊孕能について検討した。対象は交通事故 8 例，労動災害 2 例，ホームと電車にはさまれた者 1 例，飛び下り自殺未遂 1 例の計 14 例である。形成術 時の年䶨は18歳から42歳平均26.5歳である，後部尿道狭窄に対してBadenoch 法（pull through 法）を 8 例に尿道端々吻合形成術を 6 例に行った．精液検査は術後 3 カ月から 4 年目に行った．精液量をみる と $2 \mathrm{ml}$ 以上を認める正常例が $83 \%$ あった。精子濃度は, $40 \times 10^{6} / \mathrm{ml}$ 以上 9 例, $40 \sim 20 \times 10^{6} / \mathrm{ml} 2$ 例, $20 \times$ $10^{6} / \mathrm{ml}$ 以下 3 例であった。運動率は $50 \%$ 以上が 9 例， $50 \sim 30 \% 3$ 例， $30 \%$ 以下 2 例であった。 WHO 基 準による精子濃度 $20 \times 10^{6} / \mathrm{ml}$ 以上かつ運動率 $50 \%$ 以上の正常精液所見をもつ症例が 7 例 $50 \%$ にられ 精子濃度だけみると 11 例 $79 \%$ が良好であった。精液中に白血球（ $(10 / \mathrm{hpf}$ ）を認めたものは 3 例あった が自覚的，他覚的にも炎症所見を認めなかった，FSH，LH，T，PRL 值を 4 例に測定したがすべて正常 範囲であった。形成術後に結婚した 2 症例のいずれの妻も妊娠に至った。後部尿道外傷性狭窄の形成術 後の妊孕能低下を危惧していたが比較的少ないことが判明した. キーワード：膜様部尿道狭窄，尿道形成術，妊孕能
} 


\section{緒言}

交通事故, 労働災害などにより骨盤骨折が起こると 後部尿道断裂そして狭窄をきたしその治療ははなはだ 困難となる、私たちは数多くの症例の手術経験から尿 道狭窄に対しての治療はほぼ満足のいく成績となって さた ${ }^{12)}$.ささらに術前に形成術後の尿失禁を心配してい たが手術経験及び理論上からも尿失禁は起さないと確 信するに至った ${ }^{3)}$. 次に私たちが危惧したことは尿道 が完全断裂することは当然海綿体の損傷も合併するこ とになりはたして性機能は保存されるのか疑問を持っ た. 後部尿道形成術後の患者についてアンケート調査 を行い全例性欲の欠如は認められず，80\%の患者は勃 起不全をきたさないことが判明した ${ }^{4)}$. 性機能の障害 が比較的少ないことから次に造精機能への障害が気に かかった。井上ら ${ }^{4}$ が少数例に精液検査を行っており， さらに症例を加えて本論文では妊孕能について検討し たので報告する。

\section{対象と方法}

現在までに当科で後部尿道損傷に対して形成手術を 54例（表 1）に行い，そのうち精液検查を行った14例， 16検体を対象とした。対象患者は交通事故10例, 労働 災害 2 例, ホームと電車にはさまれた者 1 例, 飛び降 り自殺末遂 1 例であった。尿道形成手術時の年嚙は 18 歳から 42 歳, 平均 26.5 歳である. 後部尿道狭窄に対し

表 1 後部尿道形成術の治療法*

\begin{tabular}{c|r}
\hline 術 式 & 症 例 数 \\
\hline 内視鏡的手術 & 4 \\
尿道端々吻合術 & 14 \\
pull through 法 & 29 \\
Michalowski 法 & 7 \\
\hline
\end{tabular}

*当院での初回治療
て, pull through 法を 8 例に尿道端々吻合術を 6 例に 行った。なお，手術回数は私たちが行った形成術を 1 回含めて 1 回から 10 数回受けている. 対象症例は全例 性欲が維持され勃起および射精については時期の差は 多少あるも全例可能であった。なお症例 5 は術前逆行 性射精であったが術後正常化している，精液検查は術 後 3 カ月から 4 年目に行っている.なお症例によって は手術後紹介された病院にて検査を行っている. 3 〜 5 日間の禁欲期間をおきマスターベーションにて採 取し液体化するまで30４5分室温においた後, 精液量, 精子濃度, 精子運動率, 奇形率, 精浆中の白血球数を 測定した。症例 11 と 12 では 2 回精液検査を行っている ので精子濃度と運動率はその平均值で評価した。最近 の 4 症例に血中, Testosterone, FSH, LH, Prolactin を測定した。

\section{結 果}

pull through 法を行った 8 例の術後精液所見を表 2 に示す。年歯は19歳から42歳までの青壮年である。精 液検査は尿道形成術に成功した後 1 年から 4 年目に 行っている. 精液量は 6 例に調べており， $1.5 \mathrm{ml}$ から $5.0 \mathrm{ml}$ 平均 $3.3 \mathrm{ml}$ であった。手術回数と精液量は関係 がなかった。精子濃度は症例 7 が $0.7 \times 10^{6} / \mathrm{ml}$ と高度 の之精子症を示した。その他の症例は WHO 基準值 ${ }^{5)}$ の正常精子濃度 $20 \times 10^{6} / \mathrm{ml}$ をこて, $28 \times 10^{6} / \mathrm{ml}$ か ら $223 \times 10^{6} / \mathrm{ml}$ 平均 $91.6 \times 10^{6} / \mathrm{ml}$ ときわめて良好で あった，症例 1 では12年間にわたり 10 数回の会陰部手 術及び尿道ブジーを行っていたにもかかわらず $86 \times$ $10^{6} / \mathrm{ml}$ と良好であった。精子濃度は私たちが経験した 範囲では手術回数と関係がなかった。運動率を見ると $29 \%$ から $80 \%$ 平均 $57 \%$ と良好であった。症例 4 で $29 \%$ と不良であったが総運動精子濃度 (精子濃度 $\times$ 運動率) は6 $64.7 \times 10^{6} / \mathrm{ml}$ と十分妊孕能を有していた。運動率

表 2 pull through 法による症例の術後精液所見

\begin{tabular}{|c|c|c|c|c|c|c|c|c|}
\hline $\begin{array}{l}\text { 症例 } \\
\text { No. }\end{array}$ & $\begin{array}{c}\text { 手術時 } \\
\text { 年齢(歳) }\end{array}$ & $\begin{array}{l}\text { 手術 } \\
\text { 回数 }\end{array}$ & $\begin{array}{c}\text { 術後より検相 } \\
\text { までの期間 } \\
\end{array}$ & $\begin{array}{l}\text { 精液量 } \\
(\mathrm{ml}) \\
\end{array}$ & $\begin{array}{l}\text { 精子濃度 } \\
\left(\times 10^{6} / \mathrm{ml}\right)\end{array}$ & $\begin{array}{c}\text { 運動率 } \\
(\%)\end{array}$ & $\begin{array}{c}\text { 奇形率 } \\
(\%)\end{array}$ & 白血球数 \\
\hline 1 & 38 & 10数回 & 4 年 & & 86 & 60 & 12 & \\
\hline 2 & 19 & 1 & 3 年 & 3 & 66 & 60 & 30 & \\
\hline 3 & 34 & 1 & 2 年 & & 70 & 80 & 40 & \\
\hline 4 & 19 & 2 & 2 年 & 1.5 & 223 & 29 & & \\
\hline 5 & 35 & 1 & 6 力月 & 3 & 58 & 50 & 6 & \\
\hline 6 & 27 & 2 & 7.5 力月 & 5 & 28 & 75 & 21 & \\
\hline 7 & 42 & 4 & 7 力月 & 3 & 0.7 & 50 & & $2-3 / \mathrm{hpf}$ \\
\hline 8 & 23 & 3 & 1 年 & 4 & 110 & 49 & 6 & $8-10 / \mathrm{hpf}$ \\
\hline
\end{tabular}

*症例 1-4 はすでに文献4)に発表していることを付記する. 
表 3 尿道端々吻合術による症例の術後精液所見

\begin{tabular}{|c|c|c|c|c|c|c|c|c|}
\hline $\begin{array}{l}\text { 症例 } \\
\text { No. }\end{array}$ & $\begin{array}{c}\text { 手術時 } \\
\text { 年齢(歳) }\end{array}$ & $\begin{array}{l}\text { 手術 } \\
\text { 回数 }\end{array}$ & $\begin{array}{c}\text { 術後より検查 } \\
\text { までの期間 }\end{array}$ & $\begin{array}{l}\text { 精液量 } \\
(\mathrm{ml})\end{array}$ & 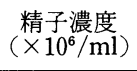 & $\begin{array}{l}\text { 運動率 } \\
(\%)\end{array}$ & $\begin{array}{c}\text { 奇形率 } \\
(\%)\end{array}$ & 白血球数 \\
\hline 9 & 20 & 4 & 55 力月 & 1.5 & 16 & 49 & & \\
\hline 10 & 23 & 1 & 1 年 5 力月 & 4.0 & 45 & 17 & 12 & 多数/hpf \\
\hline \multirow[t]{2}{*}{11} & 18 & 1 & 3 力月 & 0.5 & 16 & 14 & 13 & $20-25 / \mathrm{hpf}$ \\
\hline & & & 5 力月 & 3.5 & 26 & 70 & 15 & $15-20 / \mathrm{hpf}$ \\
\hline \multirow[t]{2}{*}{12} & 24 & 1 & 6 力月 & 3.2 & 18 & 61 & 37 & $13-15 / \mathrm{hpf}$ \\
\hline & & & 9 力月 & 2.5 & 12 & 57 & 13 & $5-6 / \mathrm{hpf}$ \\
\hline 13 & 18 & 1 & 9 カ月 & 2.5 & 316 & 92 & 7 & 0 \\
\hline 14 & 31 & 6 & 1 年 3 力月 & $>1$ & 110 & 82 & 11 & 0 \\
\hline
\end{tabular}

$50 \%$ こえた症例は 8 例中 6 例 $75 \%$ と高率であった. 奇形率は 6 例に調べられて打り $6 \%$ から $34 \%$, 平均 19\%と低率であった。精浆中に白血球が認められた症 例は記載のあった 2 例で, 膿精液症の診断を $10 / \mathrm{hpf}$ 以 上とすると 2 例ともとれ以下であった. pull through 法を行った 8 例中 WHO の正常基準值精子濃度 $20 \times$ $10^{6} / \mathrm{ml}$ 以上かつ精子運動率 $50 \%$ 以上を示した正常精 液所見例は 4 例 $50 \%$ であった。

尿道端々吻合術を行った 6 例 8 検体の術後精液所見 を表 3 に示す。年齢は 18 歳から31歳平均 22.3 歳と若い 青年が多かった．精液量は $0.5 \mathrm{ml}$ から $4 \mathrm{ml}$ 平均 $2.3 \mathrm{ml}$ であった。症例 11 は術後 3 力月目に $0.5 \mathrm{ml}$ と減少して いたが 5 カ月目には $3.5 \mathrm{ml}$ と正常量となった. 他の症 例は比較的精液量は保たれていた。手術を 6 回受けた 症例14は採取時にこぼしたとのことで $1 \mathrm{ml}$ 以上は射出 されており手術の影響はなかったと思われる. 精子濃 度は $16 \times 10^{6} / \mathrm{ml}$ から $316 \times 10^{6} / \mathrm{ml}$ 平均 $87 \times 10^{6} / \mathrm{ml}$ と 良好であった。WHO の正常基準値を越光た症例は 6 例中 2 例 $33 \%$ であった。症例14は 6 回の手術を受けて いるが, $110 \times 10^{6} / \mathrm{ml}$ ときわめて良好であった。運動率 を見ると $17 \%$ か $92 \%$ 平均 $57 \%$ と良好であった。 WHO の正常基準を越えた症例は 6 例中 3 例 $50 \%$ と比 較的良好であった。精浆中に白血球を認めた症例は調 ベられた 5 例中 3 例に見られ膿精液症であった。しか しながら全例経過中精巣上体炎, 前立腺炎等の炎症所 見を認めず症状もなかった。

内分泌検査を行った 4 症例の結果を表 4 に示す. $\mathrm{FSH} \quad 1.8 \sim 6.0 \mathrm{mIU} / \mathrm{ml}$ 平均 $4.0 \mathrm{mIU} / \mathrm{ml}, \mathrm{LH}$ は $2.3 \sim 6.6 \mathrm{mIU} / \mathrm{ml}$ 平均 $4.5 \mathrm{mIU} / \mathrm{ml}$, とゴナドトロピン 值は正常であった. $\mathrm{T}$ は $3.5 \sim 8.1 \mathrm{ng} / \mathrm{ml}$ 平均 $6.1 \mathrm{ng} / \mathrm{ml}$ で正常範囲内であった. PRLは 3 例に調べており $5.8 \sim 14.2 \mathrm{ng} / \mathrm{ml}$ 平均 $10.3 \mathrm{ng} / \mathrm{ml}$ と正常であった。

手術後に結婚したと報告してきた症例が 2 例あり,
表 44 症例の内分泌学的検查所見

\begin{tabular}{c|c|c|c|c}
\hline $\begin{array}{c}\text { 症例 } \\
\text { No. }\end{array}$ & $\begin{array}{c}\mathrm{FSH} \\
(\mathrm{mIU} / \mathrm{ml})\end{array}$ & $\begin{array}{c}\mathrm{LH} \\
(\mathrm{mIU} / \mathrm{ml})\end{array}$ & $\begin{array}{c}\mathrm{T} \\
(\mathrm{ng} / \mathrm{ml})\end{array}$ & $\begin{array}{c}\mathrm{PRL} \\
(\mathrm{ng} / \mathrm{ml})\end{array}$ \\
\hline 11 & 6.0 & 3.9 & 3.5 & 5.8 \\
12 & 4.9 & 6.6 & 7.7 & - \\
13 & 1.8 & 2.3 & 5.1 & 11 \\
14 & 3.1 & 5.3 & 8.1 & 14.2 \\
\hline
\end{tabular}

そのいずれの症例も妻が妊娠に至った，症例10は昭和 62 年 4 月尿道端々吻合術を施行し 1 年 5 力月後の精液 所見は運動率 $17 \%$ と不良であったが精子濃度は $45 \times$ $10^{6} / \mathrm{ml}$ と良好であった。平成 2 年春, 結婚され同年 10 月妻が妊娠したと連絡してきた症例である。2例目は 症例14で, 後述するように 6 回の手術を受けたにもか かわらず精液所見はきわめて良好で結婚した後すぐに 妻が妊娠に至った。

症例を呈示する。 症例 8 . S.E. 23 歳.

現病歴：昭和 61 年 7 月交通事故にて骨盤骨折, 膀胱 破裂, 尿道完全断裂にて某医にて膀胼瘻を造設された。 同年11月 interlocking を施行されたが不成功に終 わった。 その後肝炎となり加療された後昭和 63 年 2 月 13日当科へ紹介された. 手術前, 膀胼㾞からの膀脂撮 影々逆行性尿道撮影を同時に行った(図 1). 末梢端の 狭窄は膜様部であったが中枢端は不明なため狭窄の長 さは分からなかった. 同年 4 月尿道形成術を行った. 最初, 端々吻合をめざしたが欠損部が長いため pull through 法を行った. 術後尿失禁を認めず自然排尿が 可能となったが徐々に尿の勢いが無くなり, 術後約 3 カ月目の尿道撮影では図 2 のごとく pull through し た部に狭窄を認めた。 8 月10日内視鏡的に狭窄部の洀 痕組織の切除を行った. 以後排尿状態は良好となった。 手術後 8 力月頃より朝の勃起が可能となり, 昭和 64 年 
図 1 症例 8 膀胱撮影（静止時）と逆行性尿道造影 の併用. 膜様部の完全尿道断裂を示す。静止時の膀 胱造影にて膀胱頸部は閉鎖して招り内尿道括約筋は 正常に機能している.

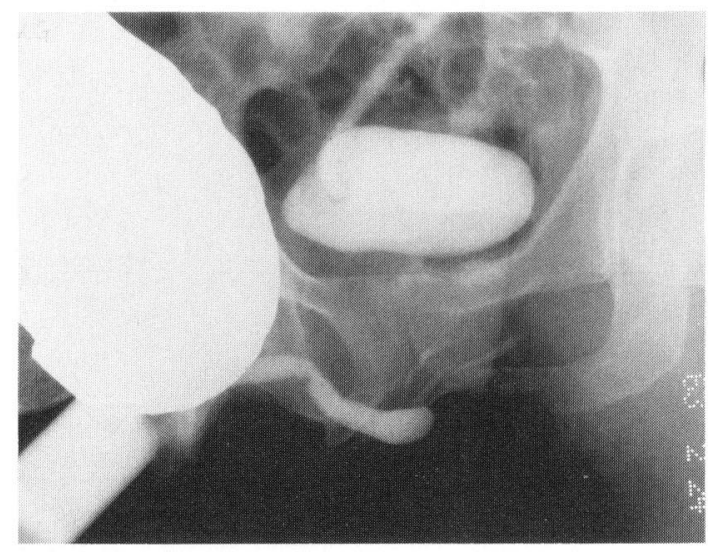

図 2 症例 8 Pull through 法術後の逆行性尿道造 影。膜様部の狭窄を認める。

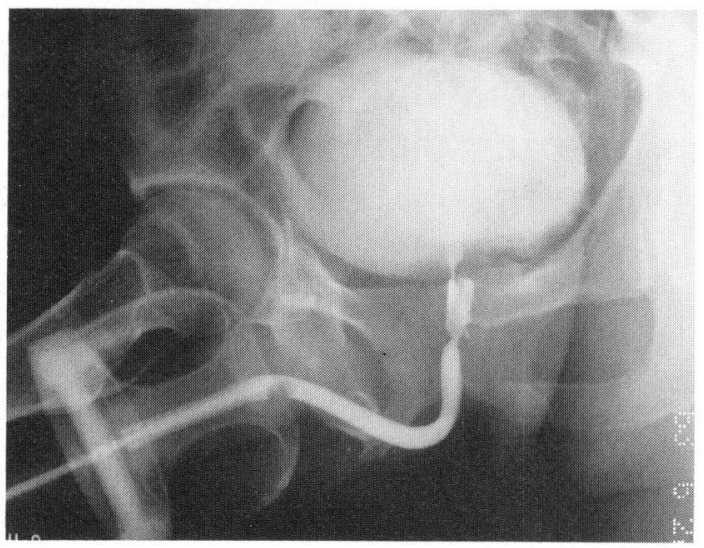

2 月射精するようになった。術後 1 年目に精液検査を 行い表 2 のごとくきわめて良好な精液所見であった。

症例14. H.S. 31歳.

9 年前に交通外傷により骨盤骨折，尿道損傷を受け た。他病院にて膀胱瘻を造設された。 その後尿道カテー テルの留置が可能となり 3 力月間留置し拔去後, 定期 的なブジーで自排尿が可能となり膀胱瘻を閉鎖した。 その後排尿困難を時々訴えていたが平成元年 4 月 13 日 尿閉となり某病院受診した。導尿が不可能なため膀脱 高位切開を掞き金属ブジーにて尿道へのカテーテルの 留置を試みたが不成功に終わり，膀胼瘦にて同年 6 月 29 日当院へ紹介された。尿道撮影にて図 3 のように膜
図 3 症例 14 逆行性尿道造影。膜様部々球部に狭窄 を認め仮性尿道と思われる尿路を通じて造影剤は後 部尿道, 膀胱へと達している。

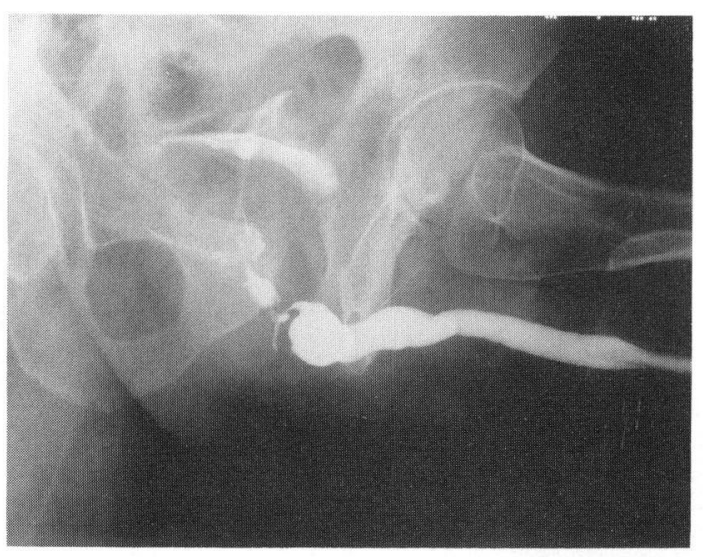

図 4 症例 14 尿道端々吻合術後の排尿時膀胱撮影々 逆行性尿道造影の併用. 端々吻合した中枢端は仮性 尿道と考えられる。

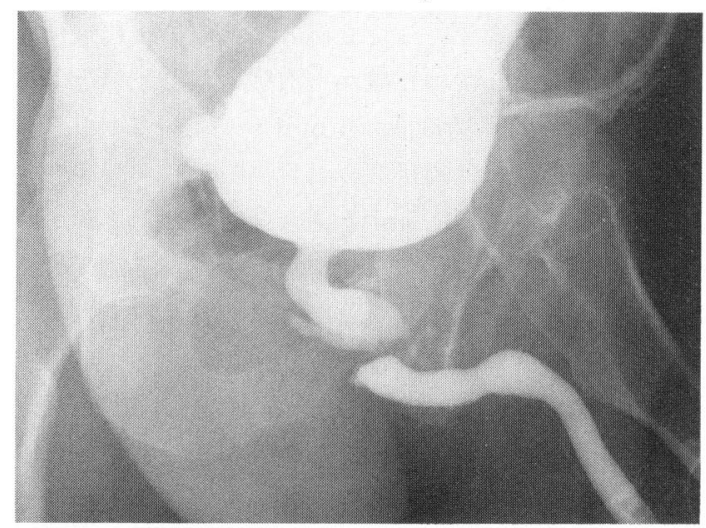

様部と球部に狭窄を認め仮性尿道己思われる尿路を通 じて造影剤は後部尿道, 膀胼へと達していた。な抢性 機能については当院に紹介前にすでに性欲はみられ， マスターベーションは可能であるが精射の勢いは弱い とのことであった。同年 8 月28日尿道端々吻合を行っ た。しかし術後排尿状態は不良ですぐに尿閉となった。 逆行性尿道撮影と膀胼撮影を併用した写真（図 4) か ら端々吻合した中枢端は仮性尿道と考兵的た。 その 後 3 回の TURにて狭窄部の䑤痕を切除し, 平成 2 年 6 月の TUR 術後より排尿状態は良好となった（図 5 ). 経過中に精巣上体炎, 前立腺炎等の炎症を認めな かった。性機能はほぼ正常に維持され，同年11月妻が 
図 5 症例14 TUR 術後の逆行性尿道造影. 膜様部 及び球部の尿道に変形を認めるが狭窄は改善されて いる。

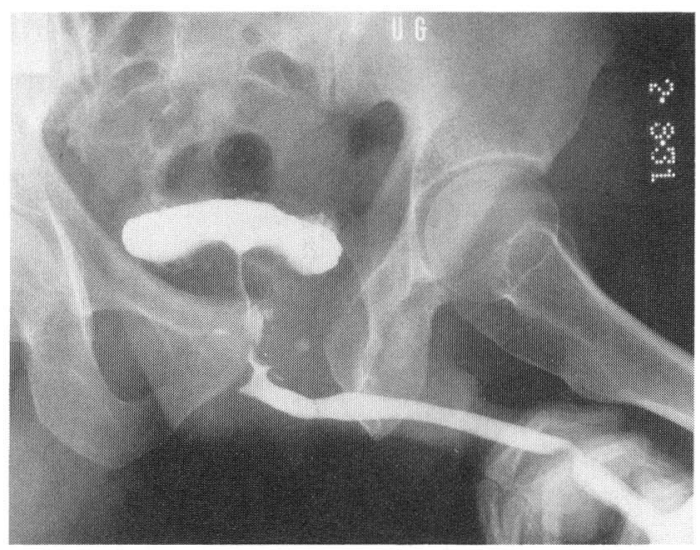

妊娠に至った。12月18日精液検査を行い表 3 のように きわめて良好な精液所見であった。なお内分泌検査は 表 4 に示すようにすべて正常範囲内であった。

\section{考察}

骨盤骨折に伴ら後部尿道狭窄の治療ははなはだ難治 な症例に遭遇することがある、尿道形成術後に尿失禁 が起こるのではないかと本手術をはじめた頃は心配し ていた。井上ら ${ }^{6)}$ は術前に内尿道括約筋が保存されて いるかどうかを判定する検査として, 膀胼撮影の静止 時（at rest）でのレ線写真で膀胱頚部が閉鎖している 所見, すなわち造影剂が後部尿道に漏れていなければ 術後失禁は泀ぼ起こらないことを実証しこの検査法の 重要性を発表した。 そして数多くの手術経験から尿道 狭窄の術後の排尿状態に対する成績はほぼ満足すべき 状態となった。我々人間は 1 つの排尿困難という問題 が解消されると欲が出てくるもので次に患者よりイン ポテンスについて相談を受けた。

\section{インポテンスについて}

骨盤骨折による後部尿道損傷は完全な尿道断裂を来 し球部に達する尿道周囲の骨盤神経が損傷され同時に 血管も損傷されることから勃起に重大な影響を及ぼ す.このよらな尿道損傷後のインポテンスについては 文献上その類度は $68 \%$ からインポテンスが起こらない とする報告京である7 111. しかしこの問題について従 来あまり検討されていないことから, 井上らは1981年 この問題を取り上げた。術後 2 年以上経過した性の成 熟した10例 (pull through 法を行った 7 例, Michalowski 法を行った 3 例）にアンケート調査しその内 7 人
は面接して性機能について話をきいた。その結果，全 例に性欲は維持しておりインポテンスはわずか 2 例 20\%であった。形成術の治療によって起きたと思われ る症例も含まれることから骨盤骨折による器質的性機 能障害はより低い頻度約 $10 \%$ ぐらいであろらと井上は 推定した。亦たさらに症例を重称て Osada $5^{12)}$ は成人 20例を対象として質問紙法による性機能障害について 調査したところインポテンスは 5 例 $25 \%$ に認めたが 2 例は心因性と診断してカウンセリングにより勃起が回 復した大変貴重な症例を経験している。セックスパー トナーのいる 8 例は性交可能 4 例, ときに性交可能 1 例, 性交不能 2 例不明 1 例と半数以上は性交可能で あった. 分析結果により Osadaらはインポテンスは外 傷の程度によって左右され尿道形成術による手術侵襲 はインポテンスに影響を及ぽさないと述べている。

射精障害について

射精は生殖器管より分泌物が尿道前立腺部に排泄さ れるまでの emission と分泌物が尿道前立腺部から膜 様部を通って外尿道口より射出される ejaculationの 過程がある。前者は下腹神経の刺激に骨盤神経が正常 に保たれていることが必要である，後者は陰部神経と 下腹神経によってコントロールされている6). 従って, 骨盤骨折の程度及び形成手術の侵襲によって射精障害 を来すことがある。このような後部尿道損傷後の射精 障害の頻度についての報告も見当らない. 私たちの今 までの経験では33例中 5 例15\%程度である。その内 4 例はインポテンスを伴っているが 1 例は勃起が可能で あるにもかかわらず射精はみられない。また受傷後逆 行性射精となっていた症例が尿道形成術後順行性に射 出可能となった例を経験している．結局，インポテン スを来さなければ射精障害はきわめて起こりにくいと 言える。

\section{造精機能について}

インポテンス拈よび射精障害が比較的少ないことが 判明したことから次に造精機能障害すなわち妊㝋能へ の影響について気になった。形成術時に狭窄部の瘵痕 切除は奥深いところで行われるため盲目的となり射精 管開口付近は破壊され閉塞してしまうのではないかと 考えていた。㐬た受傷後および形成術後に長期尿道力 テーテルの留置が余儀なくされることから前立腺, 精 囊そして精巣，精巣上体等生殖器管への影響が心配さ れたため精液検査を行った。

精液量についてみると私たちは最初, 感覚的に量が 少なくなるのではないかと危惧したが $1 \mathrm{ml}$ 以下は16検 
表 5 後部尿道形成術後の精液所見（14例）

\begin{tabular}{c|c|c|c}
\hline \multirow{2}{*}{ 精子濃度 $\left(\times 10^{6} / \mathrm{ml}\right)$} & \multicolumn{3}{|c}{ 運 動 率 $(\%)$} \\
\cline { 2 - 4 } & $0-30$ & $30-50$ & $>50$ \\
\hline $0-20$ & & 1 & 2 \\
$20-40$ & & 1 & 1 \\
$>40$ & 2 & 1 & 6 \\
\hline
\end{tabular}

体中 1 例のみで $\mathrm{WHO}$ 基準の $2 \mathrm{ml}$ 以上の正常検体は 10 検体 $63 \%$ と十分な量が射出されることが判明した。

精子濃度については $40 \times 10^{6} / \mathrm{ml}$ 以上の症例が 14 例 中 9 例, $64 \%, 40 \sim 20 \times 10^{6} / \mathrm{ml}$ の症例は 2 例, $20 \times 10^{6}$ / $\mathrm{ml}$ 以下の症例は 3 例 $21 \%$ でった. WHO 基準值 $20 \times$ $10^{6} / \mathrm{ml}$ 以上の正常例は 14 例中 11 例と $79 \%$ 症例が良 好な精子濃度を認めた。私たちが調べ得た唯一の外国 文献は Zayas ${ }^{13)}$ の文献で彼らの精液所見は, 精子濃 度の夕報告されておりそれによると 6 例中 5 例が $60 \times$ $10^{6} / \mathrm{ml}$ から $288 \times 10^{6} / \mathrm{ml}$ を有し極めて良好な成績で あった。しかし 1 例は無精子症でその原因は記載され ていなかった. 精子濃度を pull through 法と尿道端々 吻合術法とで比較すると少数例ではあるが差がないと 考えられた。また手術回数についても影響が少ないも のと思われた。

精子運動率を見ると $\mathrm{WHO}$ 基準の $50 \%$ 以上を持つ 正常例は14例中 9 例で $64 \%$ の症例が良好な精子運動を 認めた。 $50 \sim 30 \%$ 症例は 3 例，30\%以下の症例は 2 例であった。

$\mathrm{WHO}$ 基準による精子濃度 $20 \times 10^{6} / \mathrm{ml}$ 以上かつ運 動率 $50 \%$ 以上を持つ症例は 14 例中 7 例で症例の半数が 正常の精液所見を示し, 精子濃度 $20 \times 10^{6} / \mathrm{ml}$ 以下で運 動率 $30 \%$ 以下のきわめて不良な症例は 1 例も見られず 造精機能障害を来す症例は少数例であることが判明し た（表 5 ）.

精液中に白血球（>10/hpf）が存在していた症例が 3 例しかなかった。 全例経過中に副性器の炎症を認め ておらず，また精液検査時にも自覚症状は何ら訴えて いない，日常の不妊外来においても時に何ら自覚的あ るいは他覚的にも所見を認めないにもかかわらず膿精 液症を認めることがある。不妊外来で見られる頻度よ り本症のような長期のカテーテル留置そして手術, さ らに術後にブジーによる尿道抎張を必要とする本疾患 の方が膿精液症となりやすいと考えていたが, 以外に 少ないことが判明した。 今回のデーターからは膿精液 症が尿道端々吻合術法の方に多くみられる印象を持つ
が症例数が少ないことから今のところは手術法による 差はないと考えている。

内分泌検査が正常なことから受傷より尿道形成術そ して術後の経過が直接視床下部一下垂体一精巣系に影 響を打よぼしていないと考兄られた。

妊娠例が 2 例見られたことは本疾患によって不妊に なってしまらのではないかと心配している患者にとっ て勇気づけられる朗報といえる。

外傷性の骨盤骨折による尿道損傷は今後ますます増 加すると思われるが以上の結果より尿道形成術後の後 遺症として妊孕能の低下はさほど心配する必要がない と考えられた。

尿道形成術後の造精機能障害についての報告はほと んど見られず少数例ではあるが貴重なデーターと考兄 報告した。

なお，本論文の要旨は第35回日本不妊学会総会において 発表した。

\section{文献}

1）井上武夫, 長田尚夫, 平野昭彦, 田中一成, 福島修 司, 松岡俊介, 岩本晃明: 尿道狭窄の手術療法。日 泌尿会誌，64，113-120，1973.

2) 井上武夫, 長田尚夫, 田中一成, 平野昭彦, 福島修 司, 岩本晃明：尿道狭窄の手術的療法II報。日泌尿 会誌，68，383-390， 1977.

3）井上武夫, 長田尚夫, 田中一成, 平野昭彦: 尿道狭 窄の手術的療法III報。後部尿道形成術の知見捕遗. 日泌尿会誌，69，902-910，1988.

4）井上武夫, 長田尚夫, 田中一成, 平野昭彦: 尿道狭 窄の手術療法IV報。骨盤骨折飞伴万後部尿道外傷 性狭窄の形成術後の性機能について. 日泌尿会誌, 72, 979-985, 1981.

5) WHO Laboratory Manual for the Examination of Human Semen and Semen-cervical Mucus Intervaction. World Health Organization, p. 27, 1987, Cambridge Great Britain

6) 井上武夫, 長田尚夫, 平野昭彦, 工藤 治, 黒田 俊, 大山 登, 田中一成: 尿道狭窄の手術療法 $\mathrm{V}$ 報。骨盤骨折による後部尿道狭窄の形成術後の尿 失禁について。日泌尿会誌，77，415-420， 1986.

7) Chambers, H.L. and Balfour, J.: The incidence of impotence following pelvic fracture with associated urinary tract injury. J. Urol., 89, 702-703, 1963.

8) Gibson, G.R.: Urological management and complications of fractured pelvis and ruptured urethra. J. Urol., 111, 353-355, 1974.

9) Jackson, D.H. and Williams, J.L.: Urethral injury. A retrospective study. Brit. J. Urol., 46, 665-676, 1974. 
10) Coffield, K.S. and Weems, W.L.: Experience with management of posterior urethral injury associated with pelvic fracture. J. Urol., 117, 722-724, 1979 .

11）碓井 亜, 仁平寛巳, 平山多秋：骨盤骨折に伴う尿 路損傷. 救急医学, 3, 1437-1444, 1979 。

12) Osada, T., Inoue, T., Iwamoto, T. and Yajima, M.: Sexual disturbances following surgical repair $\mathrm{f}$ membraneous urethral rupture associated with pelvic fracture. Impotence, 3, 119-128, 1988.

13) Penazayas, E. De La, Z.E., Esteva, J.F., Diaz, R. P., Romero, M.A.M. and Dominguez, H.B. : Pubectomy for repair of membranous urethral stricures. J. Urol., 121, 170-172, 1979.

（1991年12月17日受理） 